\title{
Taxonomic note: speciation within the operational group Bacillus amyloliquefaciens based on comparative phylogenies of housekeeping genes
}

\author{
Mohamad Syazwan Ngalimat ${ }^{\mathrm{a}}$, Suriana Sabri ${ }^{\mathrm{a}, \mathrm{b}^{*}}$ \\ ${ }^{a}$ Ensyme and Microbial Technology Research Center, Faculty of Biotechnology and Biomolecular Sciences, Universiti Putra Malaysia, 43400, \\ Serdang, Selangor, Malaysia \\ ${ }^{b}$ Department of Microbiology, Faculty of Biotechnology and Biomolecular Sciences, Universiti Putra Malaysia, 43400, Serdang, Selangor, \\ Malaysia
}

Received 1 st November 2019 / Accepted 4th March 2020

\begin{abstract}
Many of the publically available Bacillus 16S rRNA genes and genomes in the NCBI database are inconsistently assigned as B. amyloliquefaciens. The highly conserved nature of the 16S rRNA gene makes it fail to differentiate species within the operational group $B$. amyloliquefaciens. Here, comparative phylogenies of the complete $16 \mathrm{~S} r \mathrm{rNA}, \operatorname{gyr} B, \operatorname{rpo} B, \operatorname{trp} B, \operatorname{rec} A$, and $\operatorname{che} A$ nucleotide sequences of bacterial strains within the operational group were analyzed. As the result, the $g y r B, r p o B$, and $\operatorname{trp} B$ phylogenetic analyses showed stable topology that comprised three monophyletic clades: (i) B. amyloliquefaciens; (ii) $B$. siamensis; and (iii) B. velezensis. Phylogenies derived by comparison of the $\operatorname{gr} r, \operatorname{rpo} B, \operatorname{trp} B, \operatorname{rec} A$, and $\operatorname{che} A$ with the 16S rRNA gene-derived phylogeny was significant as evaluated by the likelihood ratio test. The $\operatorname{trp} B, \operatorname{spo} B$, and $\operatorname{trp} B$ gene-derived phylogenies provide a tool for speciation within the operational group $B$. amyloliquefaciens.
\end{abstract}

Keywords: B. amyloliquefaciens identification; phylogenetic analyses of $g y r B, \operatorname{rob} B, \operatorname{tr} B, \operatorname{rec} A, \operatorname{che} A$ and $16 \mathrm{~S}$ rRNA genes

Bacillus amyloliquefaciens was first discovered by a Japanese scientist, Juichiro Fukumoto, in the soil (Fukumoto, 1943). The species is named after its unique character as it produces (faciens) a liquefying (lique) amylase (amylo) (Priest et al., 1987). B. amyloliquefaciens strains are capable of producing different bioactive compounds useful in bio-control of plant and human pathogens (Balhara et al., 2011). This bacterial species is widely distributed in various niches including soil (Lončar et al., 2013), foods (Krawczyk et al., 2016), fruits (Wu et al., 2017), bee products (Ngalimat et al., 2019), animal faeces (Singh et al., 2013), and aquatic environments (Daas et al., 2018).
Taxonomically, the operational group $B$. amyloliquefaciens belonged to the group B. subtilis species complex, family Bacillaceae, class Bacilli, and phylum Firmicutes (Berkeley et al., 1984; Fritze, 2004). This operational group is comprised of three species: B. amyloliquefaciens, B. siamensis, and B. velezensis (Fan et al., 2017). Moreover, B. amyloliquefaciens has been sub-divided into two subspecies: B. amyloliquefaciens subsp. plantarum and subsp. amyloliquefaciens. The subspecies division was based on phylogenetic analysis and physiological characteristics i.e. production of plant growth hormones/antibiotics and abilities for plant root colonization (Borriss et al., 2011).

*Author for correspondence: Suriana Sabri, Department of Microbiology, Faculty of Biotechnology and Biomolecular Sciences, Universiti Putra Malaysia, 43400 Serdang, Selangor, Malaysia. Email - suriana@upm.edu.my 
Therein, some strains of B. amyloliquefaciens subsp. plantarum, such as FZB42 (Borriss et al., 2011), was reported as being synonymous to $B$. velezensis based on phylogenomic analysis (Dunlap et al., 2016). Therefore, it is a cryptic controversy to the sequences deposited in the NCBI database could be incorrectly assigned as B. amyloliquefaciens.

For many years, it has been recognized that the group B. subtilis species complex is hard to be distinguished using classical taxonomy parameters: morphological and physiological characteristics, cell wall compositions, 16S rRNA sequence, fatty acid methyl ester analysis (FAME), and $\mathrm{G}+\mathrm{C}$ content (Rooney et al., 2009). The determination of DNA-DNA relatedness (DDH) also often shows erroneous and variable results (Auch et al., 2010). Due to these limitations, the taxonomic status of Bacillus spp. is constantly bringing confusion to researchers, especially for non-professional taxonomy researchers. Thanks to the new approaches in the next-generation sequencing (NGS) technology, bacterial genome sequencing has helped to identify bacterial species through phylogenomic analysis (Chan \& Ragan, 2013; Fan et al., 2017). Furthermore, a multilocus sequence typing (MLST) also could be helpful for typing Bacillus spp. by sequence analysis of housekeeping genes (Helgason et al., 2004). Noteworthy, these phylogenomic and MLST analyses could be time-consuming and expensive for small laboratories in research institutions (Boers et al., 2012; Haas et al., 2011). Owing to these limitations, comparative phylogenies of the $16 \mathrm{~S}$ rRNA gene and the housekeeping genes were analyzed to improve speciation within the operational group B. amyloliquefaciens.

To date, the operational group $B$. amyloliquefaciens is consisted of 337 strains with validly published on the NCBI Entrez Genome Project database (https://www.ncbi.nlm.nih. gov/genome). The B. amyloliquefaciens $16 \mathrm{~S} \mathrm{rNA}$ gene clade contains species with identical $16 \mathrm{~S}$ rRNA gene sequences. Dendrograms based on complete $r p o B$ nucleotide sequences and on core genome sequences have divided the species into the B. amyloliquefaciens, B. siamensis, and B. velezensis clades, respectively (Fan et al., 2017). To aid in the comparison in the present study, comparative phylogenies of the complete $16 \mathrm{~S}$ rRNA, DNA gyrase subunit $\mathrm{B}(\mathrm{g} y r \mathrm{~B})$, RNA polymerase $\beta$ subunit $(r p o B)$, tryptophan synthase $\beta$-subunit $(\operatorname{trp} B), \quad \operatorname{Rec} A$ protein $(\operatorname{rec} A)$, and signal transduction histidine kinase CheA (che $A)$ nucleotide sequences of 40 bacterial strains within the operational group were analyzed (Table 1). Type strains including B. amyloliquefaciens subsp. plantarum FZB42, B. velezensis CBMB205, B. siamensis KCTC 13613, and B. amyloliquefaciens DSM7 were included. All the nucleotide sequences were retrieved from the NCBI Entrez Genome Project database. Multiple sequence alignment has been generated using the MEGA 7.0 software (Kumar et al., 2016) and programme ClustalX (Thompson et al., 1997). The phylogenetic tree was created according to the neighbor-joining method (Saitou \& Nei, 1987) with the $p$-distance method (Nei \& Kumar, 2000). Bootstrap analysis was based on 1,000 replications (Felsenstein, 1985). B. subtilis subsp. subtilis 168 was chosen as an outgroup. The likelihood ratio test was used for the statistical analysis (Knudsen \& Miyamoto, 2001).

As a result, it is evident that the complete 16S rRNA nucleotide sequences were not sufficient for the speciation within the operational group (Figure 1). The presence of unstable taxa was observed that makes cladistic analysis undefinable. Moreover, B. subtilis subsp. subtilis 168 failed to act as the outgroup. To elucidate the phylogenetic relationship within the operational group more precisely, the complete sequences of $g y r B, \operatorname{rpo} B, \operatorname{trp} B, \operatorname{rec} A$, and $\operatorname{che} A$ were used in the phylogenetic analyses. Phylogenies derived from the comparison of the housekeeping genes with the $16 \mathrm{~S}$ rRNA gene-derived phylogeny was significant $(P \leq 0.05)$, showing that the tree topology was optimum. The $g y r B, r p o B$, and $\operatorname{trp} B$ gene-derived phylogenies obtained (Figure 2), have the same topology as reported by Fan et al. (2017) whereas, the root of genome-based phylogeny indicated that an ancestral lineage within the operational group started by the $B$. amyloliquefaciens clade. However, the tree topologies of $\operatorname{rec} A$ and che $A$ gene-derived phylogenies were different (Figure S1). The ancestral lineage of $\operatorname{rec} A$ gene-derived phylogeny started by $B$. velezensis clade, while, che $A$ genederived phylogeny started by $B$. siamensis clade. 
Table 1. The complete sequenced 16S rRNA, gyrB, $\operatorname{pos} B, \operatorname{trp} B, \operatorname{rec} A$, and $\operatorname{che} A$ of 40 bacterial strains within the operational group $B$. amyloliquefaciens and B. subtilis subsp. subtilis 168 obtained from the NCBI database.

\begin{tabular}{|c|c|c|c|c|c|c|c|c|}
\hline \multirow[b]{2}{*}{ Bacteria } & \multirow[b]{2}{*}{ Accession } & \multicolumn{6}{|c|}{ Number of nucleotides (bp) } & \multirow[b]{2}{*}{ Isolation source } \\
\hline & & $\begin{array}{c}16 \mathrm{~S} \\
\text { rRNA }\end{array}$ & $g y r B$ & $r p o B$ & $\operatorname{trp} B$ & $\operatorname{rec} A$ & cheA & \\
\hline B. subtilis subsp. subtilis 168 & AL009126 & 1550 & 1917 & 3582 & 1203 & 1047 & 2019 & Unknown \\
\hline B. siamensis SCSIO 05746 & СР025001 & 1552 & 1923 & 3582 & 1203 & 1044 & 2019 & Sea mud \\
\hline B. siamensis XY18 & LAGT00000000 & 1525 & 1923 & 3582 & 1203 & 1044 & 2019 & Cured vanilla beans \\
\hline B. siamensis KCTC 13613 & AJVF00000000 & 1525 & 1836 & 3015 & 1203 & 1044 & 2019 & Sugar cane \\
\hline B. amyloliquefaciens subsp. plantarum FZB42 & CP000560 & 1550 & 1917 & 3582 & 1203 & 1044 & 2019 & Infected sugar beet \\
\hline B. velezensis NJN-6 & СР007165 & 1540 & 1923 & 3582 & 1203 & 1044 & 2019 & Soil \\
\hline $\begin{array}{l}\text { B. amyloliquefaciens subsp. plantarum YAU } \\
\text { B9601-Y2 }\end{array}$ & HE774679 & 1538 & 1923 & 3441 & 1203 & 1044 & 2019 & Wheat rhizosphere \\
\hline B. velezensis SRCM103691 & СР035393 & 1554 & 1923 & 3582 & 1203 & 1044 & 2019 & Food \\
\hline B. velezensis KCTC 13012 & LHCC01000000 & 1550 & 1923 & 3582 & 1203 & 1044 & 2019 & River mouth \\
\hline B. velezensis SYBC H47 & CP017747 & 1554 & 1923 & 3582 & 1203 & 1044 & 2019 & Honey \\
\hline B. velezensis CBMB205 & СР011937 & 1555 & 1923 & 3582 & 1203 & 1044 & 2019 & Rice rhizosphere soil \\
\hline B. amyloliquefaciens DSM7 & FN597644 & 1538 & 1917 & 3582 & 1203 & 1044 & 2028 & Soil \\
\hline B. amyloliquefaciens FS1092 & СР038028 & 1553 & 1923 & 3582 & 1203 & 1044 & 2019 & Food processing environment \\
\hline B. amyloliquefaciens $\mathrm{Y} 2$ & СР003332 & 1555 & 1917 & 3441 & 1203 & 1044 & 2019 & Wheat rhizosphere \\
\hline B. amyloliquefaciens SRCM101267 & CP021505 & 1550 & 1923 & 3582 & 1203 & 1044 & 2019 & Food \\
\hline B. amyloliquefaciens ZJU1 & СР041691 & 1553 & 1917 & 3582 & 1203 & 1044 & 2019 & Morus alba \\
\hline B. amyloliquefaciens ALB69 & СР029070 & 1553 & 1917 & 3582 & 1203 & 1044 & 2019 & Almond drupe \\
\hline B. amyloliquefaciens SH-B74 & СР030097 & 1554 & 1917 & 3582 & 1203 & 1044 & 2019 & Marine-sediment \\
\hline B. amyloliquefaciens ALB 65 & СР029069 & 1553 & 1917 & 3582 & 1203 & 1044 & 2019 & Alfalfa silage \\
\hline B. amyloliquefaciens UMAF6614 & СР006960 & 1554 & 1917 & 3582 & 1203 & 1044 & 2019 & Unknown \\
\hline B. amyloliquefaciens YP6 & СР032146 & 1547 & 1923 & 3441 & 1203 & 1044 & 2019 & Rhizosphere of Lolium perenne L. \\
\hline B. amyloliquefaciens B15 & СР014783 & 1555 & 1917 & 3582 & 1203 & 1044 & 2019 & Grape skin \\
\hline B. amyloliquefaciens UMAF6639 & СР006058 & 1554 & 1923 & 3582 & 1203 & 1044 & 2019 & Unknown \\
\hline B. amyloliquefaciens $\mathrm{HK} 1$ & СР018902 & 1538 & 1923 & 3582 & 1203 & 1044 & 2019 & Corn stalk residue compost \\
\hline B. amyloliquefaciens LL3 & СР002634 & 1538 & 1923 & 3246 & 1203 & 1044 & 2019 & Korean fermented food (bibimbap) \\
\hline B. amyloliquefaciens LM2303 & CP018152 & 1555 & 1917 & 3582 & 1203 & 1044 & 2019 & Wild yak dung \\
\hline B. amyloliquefaciens ALB79 & СР029071 & 1553 & 1917 & 3582 & 1203 & 1044 & 2019 & Grape \\
\hline B. amyloliquefaciens MBE1283 & СР013727 & 1556 & 1917 & 3582 & 1203 & 1044 & 2019 & $\begin{array}{l}\text { Korean traditional } \\
\text { beverage }\end{array}$ \\
\hline B. amyloliquefaciens Y14 & CP017953 & 1556 & 1917 & 3582 & 1203 & 1044 & 2019 & Rhizosphere of peanut \\
\hline
\end{tabular}




\begin{tabular}{|c|c|c|c|c|c|c|c|c|}
\hline \multirow[b]{2}{*}{ Bacteria } & \multirow[b]{2}{*}{ Accession } & \multicolumn{6}{|c|}{ Number of nucleotides (bp) } & \multirow[b]{2}{*}{ Isolation source } \\
\hline & & $\begin{array}{c}16 \mathrm{~S} \\
\text { rRNA }\end{array}$ & $\operatorname{gyr} B$ & тров & $\operatorname{trp} B$ & $\operatorname{rec} A$ & cheA & \\
\hline B. amyloliquefaciens $\mathrm{H}$ & CP041693 & 1554 & 1917 & 3582 & 1203 & 1044 & 2019 & Unknown \\
\hline $\begin{array}{l}\text { B. amyloliquefaciens subsp. amyloliquefaciens } \\
\text { KHG19 }\end{array}$ & СР007242 & 1538 & 1923 & 3441 & 1203 & 1044 & 2019 & Unknown \\
\hline B. amyloliquefaciens LFB112 & CP006952 & 1554 & 1917 & 3582 & 1203 & 1044 & 2019 & Chinese herbs \\
\hline B. amyloliquefaciens XH7 & CP002927 & 1539 & 1923 & 3246 & 1203 & 1044 & 2028 & Unknown \\
\hline B. amyloliquefaciens TA208 & СР002627 & 1559 & 1917 & 3582 & 1203 & 1044 & 2019 & Soil \\
\hline B. amyloliquefaciens WS-8 & СР018200 & 1555 & 1917 & 3582 & 1203 & 1044 & 2019 & Soil \\
\hline B. amyloliquefaciens IT-45 & CP004065 & 1559 & 1917 & 3582 & 1203 & 1044 & 2019 & Unknown \\
\hline B. amyloliquefaciens S499 & СР014700 & 1555 & 1917 & 3582 & 1203 & 1044 & 2019 & Soil \\
\hline B. amyloliquefaciens B-4 & СР031424 & 1554 & 1917 & 3582 & 1203 & 1044 & 2019 & Unknown \\
\hline B. amyloliquefaciens CC178 & CP006845 & 1543 & 1917 & 3441 & 1203 & 1044 & 1860 & Cucumber phyllosphere \\
\hline B. amyloliquefaciens MT45 & CP011252 & 1555 & 1917 & 3582 & 1203 & 1044 & 2019 & Daqu \\
\hline B. amyloliquefaciens RD7-7 & СР016913 & 1550 & 1923 & 3582 & 1203 & 1044 & 2019 & Fermented soybean paste \\
\hline
\end{tabular}




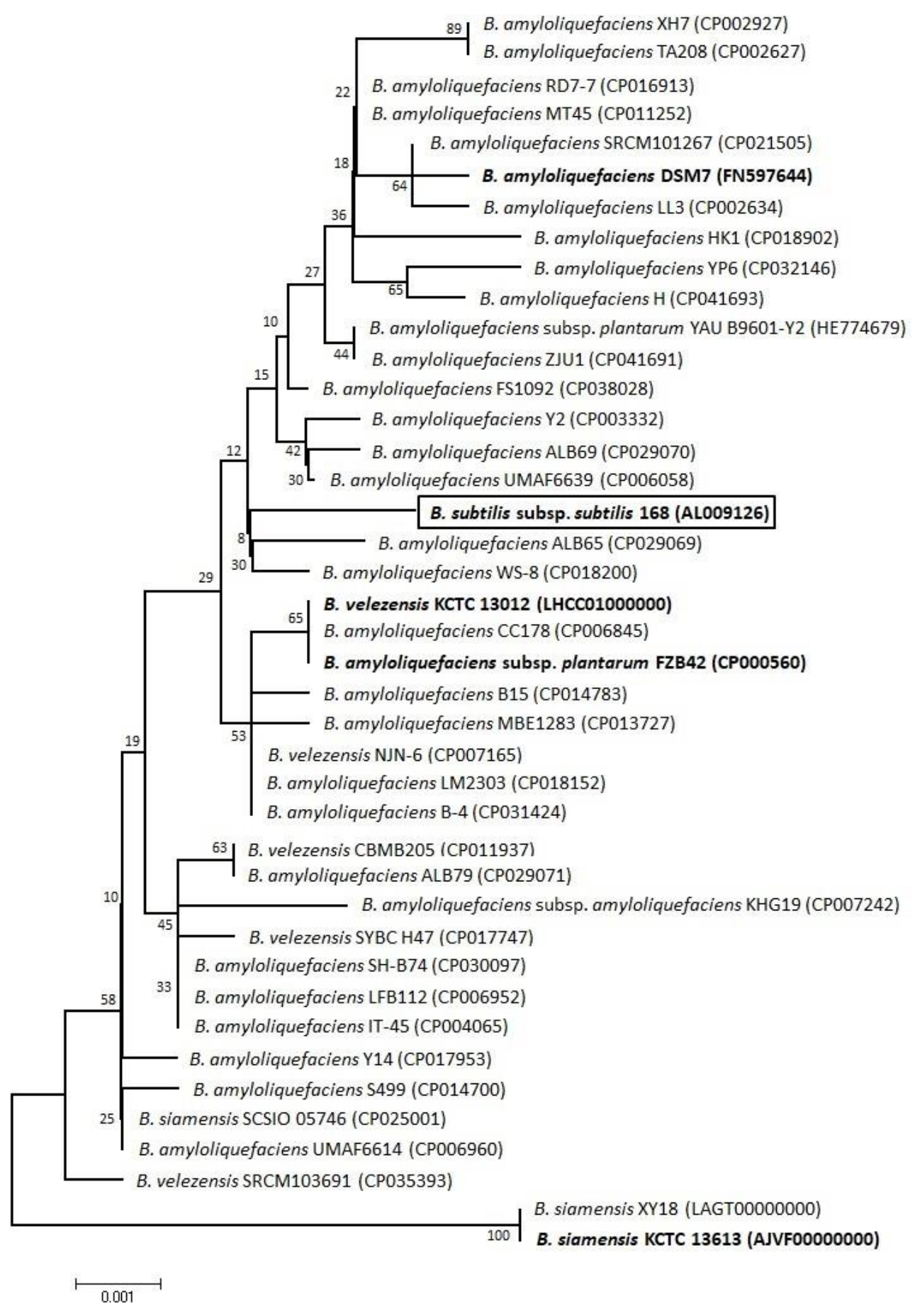

Figure 1. The $16 \mathrm{~S}$ rRNA gene phylogenetic analysis within the operational group B. amyloliquefaciens. Bootstrap values are indicated at branch points. Accession numbers for the bacterial strains are indicated within the bracket. Type strains are in bold. Noteworthy, the $16 \mathrm{~S}$ rRNA phylogenetic analysis failed to differentiate species within the operational group due to the highly conserved nature of the gene. B. subtilis subsp. subtilis 168 (in a box) failed to act as an outgroup. 


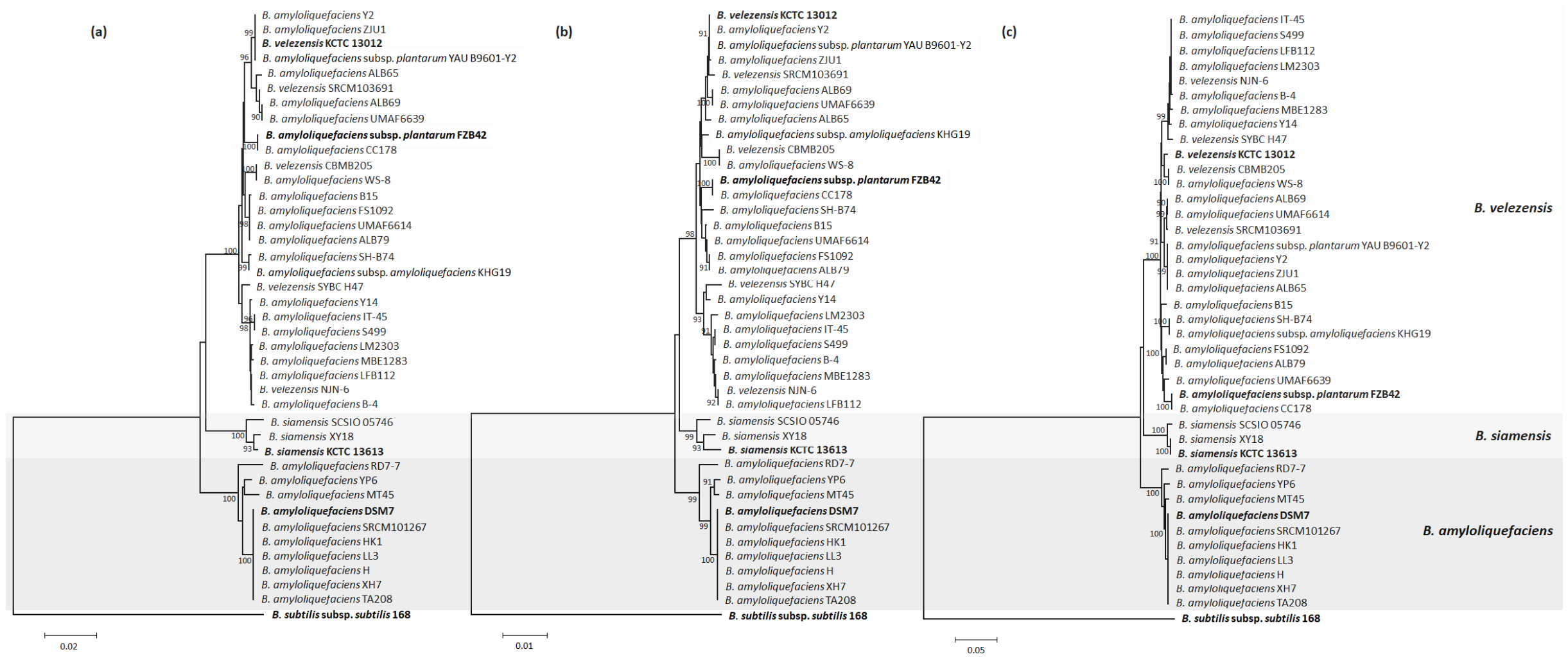

Figure 2. The phylogenetic tree analyses from 40 complete $g y r B$ (a), $r p o B$ (b), and $\operatorname{trp} B$ (c) nucleotide sequences within the operational group $B$. amyloliquefaciens. Bootstrap values $>90 \%$ are indicated at branch points. Type strains are in bold. B. subtilis subsp. subtilis 168 was chosen as an outgroup. 
In this study, $g y r B, r p o B$, and $\operatorname{trp} B$ genederived phylogenies were robust showing high bootstrap values $(>98 \%)$ for all the three clades. Based on this data, it can be concluded that the speciation of B. amyloliquefaciens, B. siamensis, and $B$. velezensis within the operational group can be confirmed by phylogenetic analysis of $g y r B, r p o B$, and $\operatorname{tr} p B$. Interestingly, $\operatorname{trp} B$ nucleotide sequences for all the strains chosen in this study were perfectly similar in size $(1,203 \mathrm{bp})$ as compared to $\operatorname{gyrB}(1,836$ - 1,923 bp) and $r p o B(3,015$ - 3,582 bp) nucleotide sequences (Table 1). Based on the phylogenetic analyses, $g r y B, r p o B$, and $\operatorname{trp} B$ have allowed speciation within the operational group. As $g r y B, r p o B$, and $\operatorname{tr} p B$ are found in the bacteria (Jablonski et al., 1996; Ogier et al., 2019; Watanabe et al., 2001), speciation within the operational group through the $g r y B, r p o B$, and $\operatorname{trp} B$ genederived phylogenies are recommended.

In summary, $g y r B, r p o B$, and $\operatorname{tr} p B$ gene-derived phylogenies in this analysis supported the whole genome-based phylogeny as proposed by Fan et al. (2017) but not 16S rRNA, rec $A$, and che $A$ genederived phylogenies. Thus, $16 \mathrm{~S} \mathrm{rRNA}, \operatorname{rec} A$, and che $A$ cannot be used for speciation within the operational group. The gyrB, $r p o B$, and $\operatorname{trp} B$ phylogenetic analyses are the promising approach for the ongoing revision on the systematic taxonomy of the operational group $B$. amyloliquefaciens. Identification of bacteria that belongs to the operational group through phylogenetic analyses of $g y r B, r p o B$, and $\operatorname{trp} B$ are strongly recommended for reliably assign novel strains or isolates to bacterial species.

\section{ACKNOWLEDGEMENTS}

This study is funded by Universiti Putra Malaysia (UPM) grant, GP-IPS/2018/9601400. Ngalimat M. S. is sponsored by UPM scholarship, GRF.

\section{REFERENCES}

Auch, A. F., Von Jan, M., Klenk, H. P., \& Göker, M. 2010. Digital DNA-DNA hybridization for microbial species delineation by means of genome-to-genome sequence comparison. Standards in Genomic Sciences 2(1): 117-134.

Balhara, M., Ruhil, S., Dhankhar, S., \& Chhillar, A. K. 2011. Bioactive compounds hold up- Bacillus amyloliquefaciens as a potent bio-control agent. The Natural Products Journal 1(1): 20-28.

Berkeley, R. C. W., Logan, N. A., Shute, L. A., \& Capey, A. G. 1984. Identification of Bacillus species. In: Methods in microbiology. pp. 292-328. Landon: Academic Press.

Boers, S. A., Van der Reijden, W. A., \& Jansen, R. 2012. Highthroughput multilocus sequence typing: Bringing molecular typing to the next level. PLoS One 7(7): e39630.

Borriss, R., Chen, X. H., Rueckert, C., Blom, J., Becker, A., Baumgarth, B., Fan, B., Pukall, R., Schumann, P., Spröer, C., \& Junge, H. 2011. Relationship of Bacillus amyloliquefaciens clades associated with strains DSM7T and FZB42T : A proposal for Bacillus amyloliquefaciens subsp. amyloliquefaciens subsp. nov. and Bacillus based on complete genome sequence comparisons. International Journal of Systematic and Evolutionary Microbiology 61(8): 1786-1801.

Chan, C. X., \& Ragan, M. A. 2013. Next-generation phylogenomics. Biology Direct 8(3): 1-6.

Daas, M. S., Acedo, J. Z., Rosana, A. R. R., Orata, F. D., Reiz, B., Zheng, J., Nateche, F., Case, R. J., Kebbouche-Gana, S., \& Vederas, J. C. 2018. Bacillus amyloliquefaciens ssp. plantarum F11 isolated from Algerian salty lake as a source of biosurfactants and bioactive lipopeptides. FEMS Microbiology Letters 365(1): fnx248.

Dunlap, C. A., Kim, S. J., Kwon, S. W., \& Rooney, A. P. 2016. Bacillus velezensis is not a later heterotypic synonym of Bacillus amyloliquefaciens; Bacillus methylotrophicus, Bacillus amyloliquefaciens subsp. plantarum and 'Bacillus oryzicola' are later heterotypic synonyms of Bacillus velezensis based on phylogenomics. International Journal of Systematic and Evolutionary Microbiology 66(3): 1212-1217.

Fan, B., Blom, J., Klenk, H. P., \& Borriss, R. 2017. Bacillus amyloliquefaciens, Bacillus velezensis, and Bacillus siamensis form an "operational group B. amyloliquefaciens" within the $B$. subtilis species complex. Frontiers in Microbiology 8: 22.

Felsenstein, J. 1985. Confidence limits on phylogenies: An approach using the bootstrap. Evolution 39(4): 783-791.

Fritze, D. 2004. Taxonomy of the genus Bacillus and related genera: The aerobic endospore-forming bacteria. Phytopathology 94(11): 1245-1248.

Fukumoto, J. 1943. Studies on the production of bacterial amylase. I. Isolation of bacteria secreting potent amylases and their distribution. Nippon Nogeikagaku Kaishi 19: 487503.

Haas, J., Katus, H. A., \& Meder, B. 2011. Next-generation sequencing entering the clinical arena. Molecular and Cellular Probes 25(5-6): 206-211.

Helgason, E., Tourasse, N. J., Meisal, R., Caugant, D. A., \& Kolstu, A. B. 2004. Multilocus sequence typing scheme for bacteria of the Bacillus cereus group. Applied and Environmental Microbiology 70(1): 191-201.

Jablonski, P. E., Jablonski, L. M., Pintado, O., Sriranganathan, N., \& Hovde, C. J. 1996. Identification of Pasteurella multocida tryptophan synthase $\beta$-subunit by antisera against strain P1059. Microbiology 142(1): 115-121.

Knudsen, B., \& Miyamoto, M. M. 2001. A likelihood ratio test for evolutionary rate shifts and functional divergence among proteins. Proceeding of the National Academy of Sciences 98(25): 14512-14517.

Krawczyk, A. O., De Jong, A., Holsappel, S., Eijlander, R. T., Van Heel, A. J., Berendsen, E. M., Wells-Bennik, M. H., \& Kuipers, O. P. 2016. Genome sequences of 12 sporeforming Bacillus species, comprising Bacillus coagulans, Bacillus licheniformis, Bacillus amyloliquefaciens, Bacillus sporothermodurans, and Bacillus vallismortis, isolated from foods. Genome Announcements 4(3): e00103-16.

Kumar, S., Stecher, G., \& Tamura, K. 2016. MEGA7: Molecular evolutionary genetics analysis version 7.0 for bigger 
datasets. Molecular Biology and Evolution 33(7): 1870-1874.

Lončar, N., Božić, N., Lopez-Santin, J. \& Vujčić, Z. 2013. Bacillus amyloliquefaciens laccase - from soil bacteria to recombinant enzyme for wastewater decolorization. Bioresource Technology 147: 177-183.

Nei, M., \& Kumar, S. 2000. Molecular evolution and phylogenetics. New York: Oxford University Press.

Ngalimat, M. S., Raja Abd. Rahman, R. N. Z., Yusof, M. T., Syahir, A., \& Sabri, S. 2019. Characterisation of bacteria isolated from the stingless bee, Heterotrigona itama, honey, bee bread and propolis. PeerJ 7: e7478.

Ogier, J. C., Pages, S., Galan, M., Barret, M., \& Gaudriault, S. 2019. $\sim_{p o B}$, a promising marker for analyzing the diversity of bacterial communities by amplicon sequencing. $B M C$ Microbiology 19(1): 171.

Priest, F. G., Goodfellow, M., Shute, L. A., \& Berkeley, R. C. W. 1987. Bacillus amyloliquefaciens sp. nov., nom. rev. International Journal of Systematic and Evolutionary Microbiology 37(1): 69-71.

Rooney, A. P., Price, N. P. J., Ehrhardt, C., Swezey, J. L., \& Bannan, J. D. 2009. Phylogeny and molecular taxonomy of the Bacillus subtilis species complex and description of Bacillus subtilis subsp. inaquosorum subsp. nov. International Journal of Systematic and Evolutionary Microbiology 59(10): 2429-2436.

Saitou, N., \& Nei, M. 1987. The neighbor-joining method: A new method for reconstructing phylogenetic trees. Molecular Biology and Evolution 4(4): 406-425.

Singh, S., Moholkar, V. S., \& Goyal, A. 2013. Isolation, identification, and characterization of a cellulolytic Bacillus amyloliquefaciens strain SS35 from rhinoceros dung. ISRN Microbiology 2013.

Thompson, J. D., Gibson, T. J., Plewniak, F., Jeanmougin, F., \& Higgins, D. G. 1997. The CLUSTAL_X windows interface: Flexible strategies for multiple sequence alignment aided by quality analysis tools. Nucleic Acids Research 25(24): 4876-4882.

Watanabe, K., Nelson, J., Harayama, S., \& Kasai, H. 2001. ICB database: The gyrB database for identification and classification of bacteria. Nucleic Acids Research 29(1): 344345.

Wu, Y., Lin, H., Lin, Y., Shi, J., Xue, S., Hung, Y. C., Chen, Y., \& Wang, H. 2017. Effects of biocontrol bacteria Bacillus amyloliquefaciens LY-1 culture broth on quality attributes and storability of harvested litchi fruit. Postharvest Biology and Technology 132: 81-87. 